\title{
Expression of Pituitary Homeo Box 1 (Ptx1) in Human Non-Neoplastic Pituitaries and Pituitary Adenomas
}

\author{
Shigeyuki Tahara, Reiko Kurotani, Naoko Sanno, Ichiro Takumi, Shinichi Yoshimura, \\ R. Yoshiyuki Osamura, Akira Teramoto \\ Department of Neurosurgery, Nippon Medical School (ST, NS, IT, AT), Tokyo, Japan, Department of \\ Pathology (RK, RYO), and Molecular Life Science (SY), Tokai University School of Medicine, \\ Kanagawa, Japan
}

We investigated the localization of pituitary homeo box 1 (Ptxl) protein in five human non-neoplastic pituitaries and 73 of all types of pituitary adenomas using immunohistochemistry, and the expression of Ptx1 messenger RNA (mRNA) in 18 representative pituitary adenomas using the reverse transcriptase polymerase chain reaction (RT-PCR) technique. By immunohistochemical analysis, Ptxl protein was extensively detected in the nuclei of normal human pituitary cells. Ptxl was detected in 10/14 (71.4\%) of growth hormone (GH)-secreting adenomas, 12/12 $(\mathbf{1 0 0 \% )}$ of prolactin (PRL)-secreting adenomas, $18 / 20(90 \%)$ of adrenocorticotropic hormone (ACTH)-secreting adenomas, 6/7 (85.7\%) of thyroidstimulating hormone (TSH)-secreting adenomas, and 17/20 (85\%) of clinically non-functioning adenomas, including 9/10 (90\%) of gonadotropinsubunit-positive adenomas. Thus, there was no relationship between Ptxl expression and a particular type of pituitary adenomas. By RT-PCR analysis, Ptxl mRNA was expressed in all 18 cases of pituitary adenomas, including two cases negative for Ptxl protein by immunohistochemistry. These results suggested that Ptxl may be an universal transcription factor in both neoplastic and non-neoplastic conditions in human pituitaries. The synergistic action with other transcription factors may be speculated to determine the specific production of the anterior pituitary hormones.

Copyright (C) 2000 by The United States and Canadian Academy of Pathology, Inc.

VOL. 13, NO. 10, P. 1097, 2000 Printed in the U.S.A.

Date of acceptance: April 17, 2000.

This work was supported by Grants for Scientific Research (No.09470055 and No.10770698) from the Ministry of Education, Science and Culture of Japan, and by the Takeda Research Foundation.

Address reprint requests to: Robbert Yoshiyuki Osamura, Department of Pathology, Tokai University School of Medicine, Isehara-city, Kanagawa, 259-1193, Japan; e-mail: osamura@is.icc.u-tokai.ac.jp; fax: 81-463-911370.
KEY WORDS: Immunohistochemistry, Pituitary, Pituitary adenoma, Ptxl, Transcription factor. Mod Pathol 2000;13(10):1097-1108

The human pituitary adenomas have been classified according to their function, such as production of growth hormone (GH), prolactin (PRL), thyroidstimulating hormone (TSH), adrenocorticotropic hormone $(\mathrm{ACTH})$, follicle-stimulating hormone (FSH), and $\alpha$-glycoprotein subunit ( $\alpha$-SU). GH, PRL, and TSH have been expressed as a group among the functioning adenomas and the role of Pit-1 has been emphasized (1-6). Synergistic action of Pit-1 with various receptors, such as those on the cell membrane and nuclear receptor super families, has also been reported (7-11). Although the mechanisms of functional expression toward GH, PRL, and TSH have been investigated in detail with pituitary adenomas, their mechanisms toward the expression of other anterior pituitary hormones have not been studied extensively. Recently, several transcription factors relative to pituitary development have been introduced. Especially, transcription factors transiently expressed during pituitary development include the prophet of Pit-1 (Prop-1) and Rpx/Hesx-1 (12-14). It is known that Prop-1 acts as an early enhancer of Pit-1. Prop-1 is expressed before Pit-1 from embryonic day 10 to 10.5 (e10 to 10.5) and expression of Prop-1 peaks on e12. Pit- 1 is first expressed from e13.5, and expression of Prop-1 decreases as the expression of Pit-1 increases, whereas no Prop-1 expression is seen in adults (12). Rpx/Hes $x$ - 1 , a homeo box gene, is also expressed transiently from e9 to 14.5 during differentiation of the pituitary gland, although its function is not yet fully clarified (14). Rpx/Hesx- 1 has been reported to form a heterodimer with Prop-1 and to inhibit Pit-1 activation by Prop-1 (12), which was inferred from the finding that Rpx/Hesx-1 was expressed throughout embryonic days in Prop-1-deficient mice $(12,15)$. Because it has also been reported that pituitary hypoplasia occurs in transgenic mice with 
Rpx/Hesx-1 expression throughout embryonic days, disappearance of Rpx/Hesx-1 seems to be necessary for proper differentiation of the various types of pituitary cells (16). Therefore, the activation of Pit- 1 by Prop-1 may be triggered through the disappearance of Rpx/Hesx-1. On the other hand, a novel transcription factor pituitary homeo box 1 (Ptxl) has been initially introduced as a factor toward the expression of proopiomelanocortin (POMC) (17). But, in the studies on rat pituitary glands and cultured cells, Ptxl has been expressed not only in the POMC secreting cells but also in the other hormone secreting cells of the anterior lobe as well as in the cell lines of various different hormone productions (16). This study is aimed to elucidate the expression of Ptxl in the human pituitary adenomas of various types in order to clarify the role of Ptxl in the functional differentiation in the neoplastic conditions.

\section{MATERIALS AND METHODS}

\section{Patients}

Five human non-neoplastic pituitaries were obtained from autopsy within 4 hours postmortem of the patients without endocrinologic abnormalities, and seventy-three of pituitary adenomas (male 30, female 43; age range, 16 to 80 years) were obtained by the transsphenoidal surgery. The clinical and endocrinologic features were as follows: 14 patients with GH-secreting adenomas and symptoms of acromegaly, 12 with PRL-secreting adenomas whose serum PRL levels ranged from 120 to $2560 \mathrm{ng} / \mathrm{mL}$, 20 with ACTH-secreting adenomas and typical Cushing's syndrome, seven with TSH-secreting adenomas and hyperthyroidism, and 20 with nonfunctioning adenomas that clinically presented no evidence of anterior pituitary hormone excess and did not show high serum concentrations of any of the anterior pituitary hormone except mild hyperprolactinemia (less than $100 \mathrm{ng} / \mathrm{mL}$ ). Among those 20 cases of nonfunctioning adenomas, 12 cases involved visual disturbance, four cases involved headache, and four cases were incidentally shown to have pituitary tumors by computed tomography or magnetic resonance imaging. Most of seven cases with TSH-secreting adenomas were previously reported using immunohistochemistry and in situ hybridization by Sanno et al. $(18,19)$. These adenomas were classified based on their clinical manifestations, biological functions, and ultrastructures $(20,21)$.

\section{Tissue Preparation and Antibodies}

The tissues were routinely fixed in $10 \%$ formalin or $4 \%$ paraformaldehyde for 8 to 24 hours and em- bedded in paraffin. Serial sections were prepared for hematoxylin-eosin staining, avidin-biotin complex peroxidase $(\mathrm{ABC})$ method, or the indirect method. Polyclonal antibody for Ptxl was raised against synthetic peptide containing the following murine Ptxl amino acid residues: Ptxl 31 to 50 (FHLARAADPREPLENSASES) (22). This antibody had homology only to $20 \%$ with murine Ptx2 sequence, but to $90 \%$ with human Ptxl sequence (23).

The anti-anterior-pituitary-hormone antibodies and their dilutions used in this study were: antihuman (h) GH (1:800), anti-hPRL (1:600), antihACTH (1:800) monoclonal antibodies (DAKO, Carpinteria, CA), and anti-h-FSH $\beta$ (1:200), anti-hLH $\beta$ (1:200), anti-h-TSH $\beta$ (1:200) monoclonal antibodies (Immunotech S.A., France), and anti- $\alpha$ subunit of glycoprotein ( $\alpha$-SU; 1:100) monoclonal antibodies (Chemicon International, Inc., Temecula, CA).

\section{Light Microscopic Immunohistochemistry}

Immunohistochemical study was performed by the ABC method (24). The deparaffinized and rehydrated specimens were incubated with $0.3 \%$ hydrogen peroxidase in methanol for $30 \mathrm{~min}$ to block endogenous peroxidase activity. Then the specimens were incubated with primary antibody for $12 \mathrm{~h}$, rinsed in PBS, and subsequently incubated with biotinylated anti-rabbit immunoglobulin (Vector Laboratories, UK). Then the sections were rinsed and incubated with avidin-biotin complex (Vector Laboratories). The reaction was visualized by incubation with 3,3'-diaminobenzidine tetrahydrochloride for $3 \mathrm{~min}$, which resulted in a brown color. In the normal human pituitary glands and pituitary adenomas, the double immunostaining method was applied to determine the structural relationship between Ptxl immunoreactivity and anterior pituitary hormones as reported previously $(18,25)$. In brief, after visualizing the immunoreactivity of the Ptxl by diaminobenzidine, the antibodies were removed by rinsing the sections in a

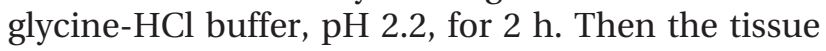
sections were incubated with anterior pituitary hormone antibodies for $1 \mathrm{~h}$, followed by incubation with alkaline-phosphatase-conjugated second antibodies (Amersham International, UK) and visualized with fast blue.

\section{Western Blotting for Ptx1 in the Pituitary Adenomas}

To confirm the specificity of Ptxl antibodies, Western blotting for Ptxl was performed in the representative GH-secreting adenoma and PRLsecreting adenoma, which were immunohistochemically positive for Ptxl protein. These tissues were homogenized in ice-cold $50 \mathrm{~mm}$ Tris- $\mathrm{HCl}, \mathrm{pH}$ 


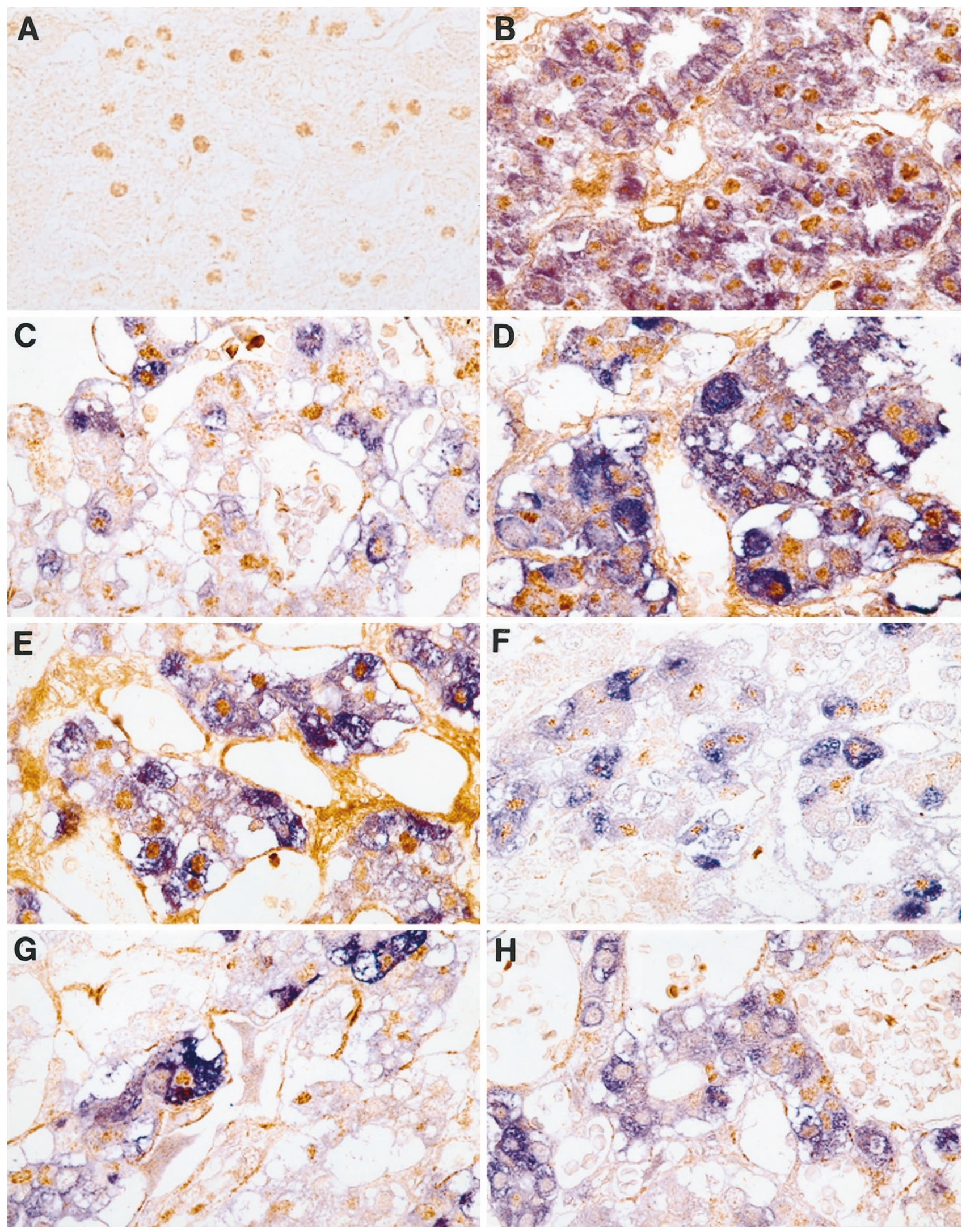

FIGURE 1. Immunohistochemistry for Ptxl protein in human non-neoplastic pituitary. A, expression of Ptxl protein is observed in the nuclei of anterior pituitary cells in a brown color. The immunopositive cells were observed about 60 to $70 \%$ of the nuclei in the anterior pituitary cells (original magnification, $500 \times$ ). B-H, double immunohistochemical staining in human non-neoplastic pituitary indicating that Ptxl immunopositivity (brown) does frequently co-localized in GH (B), ACTH (D), and $\alpha$-SU (H) immunopositive cells (blue), and does occasionally co-localized in PRL (C), FSH $\beta(\mathbf{E}), \operatorname{LH} \beta(\mathbf{F})$, and TSH $\beta$ (G) immunopositive cells (blue) (original magnification, 600×). 
7.5 , containing $2 \mathrm{~mm}$ ethylene glycol tetraacetic acid (EGTA), 1 mu dithiothreitol (DTT), and $0.001 \%$ leupeptin. Each tissue homogenate was centrifuged at $100,000 \times \mathrm{g}$ at $4^{\circ} \mathrm{C}$ for $1 \mathrm{~h}$ and the supernatants were used for electrophoresis. The protein concentration of each sample was measured and the amount of each sample applied to polyacrylamide gel was adjusted for equal loading. After electrophoresis, each sample was transferred to nitrocellulose membrane. For Western blotting of Ptxl protein, anti-Ptxl polyclonal antibodies (1:250 diluted) and subsequently HRP-labeled anti-rabbit immunoglobulin (donkey, 1:400, diluted in Tween 20PBS; Amersham International) were applied to each lane as the primary and secondary antibodies, respectively. Anti-Ptxl polyclonal antibodies used for Western blotting are the same as the ones used for light immunohistochemistry. Immunoreactivity for Ptxl protein was visualized by incubation with $3,3^{\prime}$ diaminobenzidine tetrahydrochloride for $3 \mathrm{~min}$, which resulted in a brown color.

\section{RT-PCR for Ptx1}

Total RNA extraction was performed by the single-step method (TRIzol reagent kit, Life Technologies, Gaithersburg, MD) from a representative non-neoplastic pituitary and 18 pituitary adenomas and total RNA was treated by Deoxyribonuclease I (Life Technologies). First-strand complementary DNA (cDNA) was prepared from total RNA with Deoxyribonuclease I treatment using a T-Primed First-Strand kit (Amershan Pharmacia Biotech Inc., Uppsala, Sweden). The RT reaction was performed at $37^{\circ} \mathrm{C}$ for $60 \mathrm{~min}$ in a final volume of $50 \mu \mathrm{L}$ with $5 \mu \mathrm{g}$ total RNA. For PCR, the following oligonucleotide primers were used to identify human Ptxl: up-stream 5'-TGG CTA CGT GCC GCA GTT CA-3' and down-stream 5' -GCT GTT GTA CTG GCA CGC GT-3', which generate a RT-PCR product of $470 \mathrm{bp}$. These primers were synthesized on the basis of the reported sequence of human Ptxl (23). The integrity of RNA from each specimen was verified by RT-PCR for $\beta$-actin using the up-stream primer $5^{\prime}$ GAT ATC GCC GCG CTC GTC GTC-3' and the down-stream primer 5'-GGC TGG GGT GTT GAA GGT CTC-3', which generated a RT-PCR product of $381 \mathrm{bp}$. These primers were previously reported by Fields et al. (26). The PCR was carried out in $100 \mu \mathrm{L}$ final reaction volumes containing $1 \mu \mathrm{L}$ RT reaction product as template DNA, corresponding to cDNA synthesized from 500 ng total RNA, $1 \times$ PCR buffer II, $1.0 \mathrm{mmol} / \mathrm{L} \mathrm{MgCl}_{2}, 0.2 \mathrm{mmol} / \mathrm{L}$ of each deoxynucleotide, $0.4 \mu \mathrm{mol} / \mathrm{L}$ each up-stream and down-stream primer for human Ptxl, and $2.5 \mathrm{U}$ AmpliTaq Gold (Perkin-Elmer, Norwalk, CT). Programmable temperature cycling (Perkin-Elmer, GeneAmp PCR System 9700) was performed with the following cycle profile: $95^{\circ} \mathrm{C}$ for $10 \mathrm{~min}$ as an initial denaturing step, followed by $95^{\circ} \mathrm{C}$ for $1 \mathrm{~min}$ as an amplification, and $64^{\circ} \mathrm{C}$ for $1 \mathrm{~min}$ as an annealing and extension (40 cycles) for human Ptxl; and $95^{\circ} \mathrm{C}$ for $10 \mathrm{~min}$ as an initial denaturing step, followed by $95^{\circ} \mathrm{C}$ for $1 \mathrm{~min}$ as an amplification, and $60^{\circ} \mathrm{C}$ for $1 \mathrm{~min}$ as an annealing and extension ( 40 cycles) for $\beta$-actin, respectively. Samples of the reaction products (10 $\mu \mathrm{L}$ each) were electrophoresed through $2 \%$ agarose gels with ethidium bromide and photographed under ultraviolet light. In RT-PCR experiments, total RNA from the human non-neoplastic pituitary gland without reverse transcriptase was included as a negative control for human Ptxl.

\section{RESULTS}

\section{Immunohistochemical Findings and Western Blotting}

In the five human non-neoplastic pituitary glands, Ptx1 protein was expressed in 60 to $70 \%$ of the nuclei in the anterior pituitary cells (Fig. 1A). By double staining for the anterior pituitary hormones, Ptxl immunoreactivity was observed in all types of anterior pituitary cells (Fig. 1, B-H). The endocrine cells immunoreactive for Ptxl protein in the anterior lobe of human pituitary gland were summarized in Table 1.

Seventy-three pituitary adenomas have been classified histologically on the basis of cytoplasmic staining affinities into categories of eosinophilic, basophilic, and chromophobe, and have been immunohistochemically confirmed by their hormonal expression (Table 2). Ten of 20 clinically nonfunctioning adenomas were expressed one or more of $\mathrm{FSH} \beta, \mathrm{LH} \beta$ or $\alpha$-SU, and were subclassified as gonadotropin-subunit-positive adenomas. Immunohistochemical detection of Ptxl protein was observed in 63 (86.3\%) of 73 cases of human pituitary adenomas and was expressed in the nuclei of each adenoma cells. In the pituitary adenomas that were immunohistochemically positive for Ptxl protein, the Ptxl immunopositivity was observed from scattered cells to about $70 \%$ adenoma cells, and the number of

TABLE 1. Results of Immunohistochemical Co-Localization with the Anterior Pituitary Hormones and Ptx1 Protein in Human Non-Neoplastic Pituitaries

\begin{tabular}{cc}
\hline Cell Type & Ptxl Protein \\
\hline GH & ++ \\
PRL & + \\
ACTH & ++ \\
FSH $\beta$ & + \\
LH $\beta$ & + \\
TSH $\beta$ & + \\
$\alpha$-SU & ++ \\
\hline
\end{tabular}

GH, growth hormone; PRL, prolactin; ACTH, adrenocorticotropic hormone; FSH, follicle-stimulating hormone; TSH, thyroid-stimulating hormone; $\alpha$-SU, $\alpha$-glycoprotein subunit. ++ , frequent; + , occasional. 
TABLE 2. Results of Immunohistochemical Analysis for Anterior Pituitary Hormones and Ptx1 in 73 Pituitary Adenomas

\begin{tabular}{|c|c|c|c|c|c|c|c|c|c|c|}
\hline \multirow{2}{*}{ Diagnosis } & \multirow{2}{*}{$\begin{array}{l}\text { Case } \\
\text { No. }\end{array}$} & \multirow{2}{*}{$\begin{array}{l}\text { Age/ } \\
\text { Sex }\end{array}$} & \multicolumn{8}{|c|}{ Immunohistochemistry } \\
\hline & & & GH & PRL & ACTH & $\mathrm{FSH} \beta$ & $\mathrm{LH} \beta$ & $\mathrm{TSH} \beta$ & $\alpha$-SU & Ptxl \\
\hline \multirow[t]{14}{*}{ Acromegaly } & 1 & $62 / F$ & ++ & + & - & - & - & - & + & +++ \\
\hline & 2 & $46 / \mathrm{F}$ & +++ & ++ & - & - & - & - & +++ & ++ \\
\hline & 3 & $62 / \mathrm{M}$ & +++ & +++ & - & - & - & - & - & + \\
\hline & 4 & $54 / \mathrm{M}$ & +++ & +++ & - & - & - & - & + & +++ \\
\hline & 5 & $50 / \mathrm{F}$ & ++ & + & - & - & - & - & - & - \\
\hline & 6 & $41 / \mathrm{M}$ & ++ & + & - & - & - & - & - & ++ \\
\hline & 7 & $38 / \mathrm{M}$ & +++ & +++ & - & - & - & - & ++ & + \\
\hline & 8 & $60 / \mathrm{F}$ & +++ & +++ & - & - & - & - & ++ & - \\
\hline & 9 & $22 / \mathrm{M}$ & + & + & - & - & - & - & + & +++ \\
\hline & 10 & $49 / \mathrm{M}$ & +++ & +++ & - & - & - & - & ++ & - \\
\hline & 11 & $71 / \mathrm{F}$ & +++ & +++ & - & - & - & - & + & - \\
\hline & 12 & $47 / \mathrm{F}$ & ++ & ++ & - & - & - & - & - & + \\
\hline & 13 & $66 / \mathrm{M}$ & +++ & +++ & - & - & - & - & + & +++ \\
\hline & 14 & $70 / \mathrm{F}$ & ++ & ++ & - & - & - & - & + & + \\
\hline \multirow{12}{*}{$\begin{array}{l}\text { PRL-secreting } \\
\text { adenoma }\end{array}$} & 15 & $56 / \mathrm{F}$ & - & +++ & - & - & - & - & - & ++ \\
\hline & 16 & $49 / \mathrm{F}$ & - & +++ & - & - & - & - & - & ++ \\
\hline & 17 & $21 / F$ & - & +++ & - & - & - & - & - & ++ \\
\hline & 18 & $28 / F$ & - & +++ & - & - & - & - & - & ++ \\
\hline & 19 & $21 / F$ & - & +++ & - & - & - & - & - & +++ \\
\hline & 20 & $30 / F$ & - & +++ & - & - & - & - & - & + \\
\hline & 21 & $40 / \mathrm{M}$ & - & +++ & - & - & - & - & - & + \\
\hline & 22 & $22 / \mathrm{F}$ & - & +++ & - & - & - & - & - & + \\
\hline & 23 & $27 / F$ & - & +++ & - & - & - & - & - & + \\
\hline & 24 & $25 / \mathrm{M}$ & - & +++ & - & - & - & - & - & + \\
\hline & 25 & $28 / \mathrm{F}$ & - & +++ & - & - & - & - & - & + \\
\hline & 26 & $63 / \mathrm{F}$ & - & +++ & - & - & - & - & - & + \\
\hline \multirow[t]{20}{*}{ Cushing's } & 27 & $53 / \mathrm{F}$ & - & - & +++ & - & - & - & - & ++ \\
\hline & 28 & $27 / \mathrm{M}$ & - & - & +++ & - & - & - & - & - \\
\hline & 29 & $40 / \mathrm{M}$ & - & - & + & - & - & - & - & + \\
\hline & 30 & $44 / \mathrm{F}$ & - & - & ++ & - & - & - & - & ++ \\
\hline & 31 & $41 / \mathrm{F}$ & - & - & +++ & - & - & - & - & + \\
\hline & 32 & $18 / \mathrm{M}$ & - & - & +++ & - & - & - & - & ++ \\
\hline & 33 & $27 / F$ & - & - & ++ & - & - & - & - & +++ \\
\hline & 34 & $27 / \mathrm{F}$ & - & - & +++ & - & + & - & - & + \\
\hline & 35 & $57 / F$ & + & - & + & - & - & - & + & - \\
\hline & 36 & $24 / F$ & - & - & ++ & - & - & - & + & + \\
\hline & 37 & $53 / \mathrm{F}$ & + & - & ++ & - & - & - & - & ++ \\
\hline & 38 & $50 / \mathrm{F}$ & - & - & +++ & - & - & - & - & +++ \\
\hline & 39 & $43 / \mathrm{F}$ & - & - & + & - & - & - & - & ++ \\
\hline & 40 & $51 / \mathrm{M}$ & - & - & +++ & - & - & - & - & + \\
\hline & 41 & $40 / \mathrm{F}$ & - & - & +++ & - & - & - & - & + \\
\hline & 42 & $49 / \mathrm{F}$ & - & - & +++ & - & - & - & - & +++ \\
\hline & 43 & $62 / \mathrm{M}$ & - & - & +++ & - & - & - & - & + \\
\hline & 44 & $18 / \mathrm{F}$ & - & - & +++ & - & - & - & - & +++ \\
\hline & 45 & $24 / \mathrm{M}$ & - & - & +++ & - & - & - & - & +++ \\
\hline & 46 & $18 / \mathrm{F}$ & - & - & +++ & - & - & - & - & ++ \\
\hline \multirow{7}{*}{$\begin{array}{l}\text { TSH-secreting } \\
\text { adenoma }\end{array}$} & 47 & $48 / \mathrm{M}$ & + & + & - & - & - & + & + & - \\
\hline & 48 & $41 / \mathrm{M}$ & + & + & - & - & - & ++ & + & + \\
\hline & 49 & $31 / \mathrm{F}$ & - & - & - & - & - & ++ & +++ & + \\
\hline & 50 & $44 / \mathrm{M}$ & ++ & + & - & - & - & ++ & +++ & ++ \\
\hline & 51 & $45 / F$ & ++ & ++ & - & - & - & ++ & ++ & ++ \\
\hline & 52 & $59 / F$ & + & + & - & - & - & + & ++ & + \\
\hline & 53 & $49 / \mathrm{F}$ & + & + & - & - & - & + & + & + \\
\hline \multirow[t]{10}{*}{ Null cell adenoma } & 54 & $64 / F$ & - & - & - & - & - & - & - & + \\
\hline & 55 & $47 / \mathrm{F}$ & - & - & - & - & - & - & - & ++ \\
\hline & 56 & $40 / \mathrm{F}$ & - & - & - & - & - & - & - & ++ \\
\hline & 57 & $16 / \mathrm{M}$ & - & - & - & - & - & - & - & + \\
\hline & 58 & $71 / \mathrm{F}$ & - & - & - & - & - & - & - & +++ \\
\hline & 59 & $41 / \mathrm{F}$ & - & - & - & - & - & - & - & ++ \\
\hline & 60 & $51 / \mathrm{F}$ & - & - & - & - & - & - & - & +++ \\
\hline & 61 & $80 / \mathrm{M}$ & - & - & - & - & - & - & - & - \\
\hline & 62 & $62 / \mathrm{M}$ & - & - & - & - & - & - & - & +++ \\
\hline & 63 & $74 / \mathrm{M}$ & - & - & - & - & - & - & - & - \\
\hline
\end{tabular}


TABLE 2. (Continued)

\begin{tabular}{|c|c|c|c|c|c|c|c|c|c|c|}
\hline \multirow{2}{*}{ Diagnosis } & \multirow{2}{*}{$\begin{array}{c}\text { Case } \\
\text { No. }\end{array}$} & \multirow{2}{*}{$\begin{array}{c}\text { Age/ } \\
\text { Sex }\end{array}$} & \multicolumn{8}{|c|}{ Immunohistochemistry } \\
\hline & & & $\mathrm{GH}$ & PRL & ACTH & $\mathrm{FSH} \beta$ & $\mathrm{LH} \beta$ & $\mathrm{TSH} \beta$ & $\alpha-\mathrm{SU}$ & Ptxl \\
\hline \multirow{10}{*}{$\begin{array}{l}\text { Gonadotropin } \\
\text { subunit positive } \\
\text { adenoma }\end{array}$} & 64 & $80 / \mathrm{M}$ & - & - & - & +++ & - & - & + & +++ \\
\hline & 65 & $67 / \mathrm{M}$ & - & - & - & + & + & - & + & +++ \\
\hline & 66 & $63 / \mathrm{M}$ & - & - & - & ++ & - & - & + & + \\
\hline & 67 & $48 / \mathrm{F}$ & - & - & - & ++ & - & - & - & + \\
\hline & 68 & $63 / F$ & - & - & - & +++ & - & - & - & +++ \\
\hline & 69 & $79 / \mathrm{M}$ & - & - & - & + & - & - & + & + \\
\hline & 70 & $53 / \mathrm{M}$ & - & - & - & + & + & - & + & + \\
\hline & 71 & $56 / \mathrm{M}$ & - & - & - & ++ & - & - & - & ++ \\
\hline & 72 & $52 / \mathrm{M}$ & - & - & - & + & - & - & + & - \\
\hline & 73 & $62 / \mathrm{M}$ & - & - & - & + & + & - & + & ++ \\
\hline
\end{tabular}

- indicates negative; + , less than $25 \%$;,++ 25 to $50 \%$; +++ , over $50 \%$ of adenoma cells.

immunopositive cells varied from case to case (Table 2). The results of the immunohistochemical examination of the different types of adenoma are summarized in Table 3. Ptx1 protein was detected in $10(71.4 \%)$ of 14 cases with GH-secreting adenomas, all of 12 cases $(100 \%)$ with PRL-secreting adenomas, $18(90.0 \%)$ of 20 cases with ACTH-secreting adenomas, six (85.7\%) of seven cases with TSH-secreting adenomas, 17 (85.0\%) of 20 cases with nonfunctioning adenomas. In ten cases of gonadotropin-subunit-positive adenomas that were categorized in the clinically nonfunctioning adenomas, nine cases (90\%) were positive for Ptxl protein by immunohistochemistry. In Ptxl positive ACTH-secreting adenomas, which were only positive for ACTH by immunohistochemistry in most of cases, Ptxl immunopositivity was often localized in the ACTH-secreting cells (Fig. 2). In PRL-secreting adenomas, which are characterized by a "Golgi pattern" of PRL localized and only positive for PRL by immunohistochemistry in this series, Ptxl immunopositivity were occasionally expressed in PRL-secreting cells (Fig. 3). On the other hand, in GHsecreting adenomas, which were all positive for GH and PRL, and were occasionally positive for $\alpha$-SU by the immunohistochemistry in this series, Ptxl immunopositivity were coexpressed not only for GH positive adenoma cells but also for PRL and $\alpha$-SU positive adenoma cells (Fig. 4, A-C). In gonadotropin-subunit-positive ad-

TABLE 3. Immunohistochemical Detection of Ptx1 Protein in Human Non-Neoplastic Pituitaries and Pituitary Adenomas

\begin{tabular}{lcc}
\hline \multicolumn{1}{c}{ Diagnosis } & $\begin{array}{c}\text { Number } \\
\text { Studied }\end{array}$ & $\begin{array}{c}\text { Number Positive (\%) } \\
\text { Ptx1 Protein }\end{array}$ \\
\hline Non-neoplastic pituitaries & 5 & $5(100)$ \\
& 14 & $10(71.4)$ \\
GH-secreting adenomas & 12 & $12(100)$ \\
PRL-secreting adenomas & 20 & $18(90)$ \\
ACTH-secreting adenomas & 7 & $6(85.7)$ \\
TSH-secreting adenomas & 20 & $17(85)$ \\
Non-functioning adenomas & 10 & $9(90)$ \\
Gonadotropin-subunit-positive & & \\
$\quad$ adenomas ${ }^{a}$ & 73 & $63(86.3)$ \\
Total &
\end{tabular}

${ }^{a}$ Ten adenomas of clinically nonfunctioning adenomas immunohistochemically expressed one or more of $\mathrm{FSH} \beta, \mathrm{LH} \beta$, or $\alpha$-SU, and were subclassified as gonadotropin-subunit-positive adenoma. enomas, which were immunohistochemically positive for one or more of $\mathrm{FSH} \beta, \mathrm{LH} \beta$ or $\alpha$-SU, Ptxl protein was coexpressed for gonadotropin-subunit-positive adenoma cells (Fig. 5, A-B). Thus, Ptxl protein was expressed in the pituitary adenoma cells that produced various pituitary hormones and in the GH-secreting adenomas and gonadotropin-subunit-positive adenomas that were immunohistochemically and frequently multihormonal.

To confirm the specificity of Ptxl antibodies, Western blotting for Ptxl was performed in the representative GH-secreting adenoma and PRLsecreting adenoma, indicating the case of No. 1 and 19, respectively, in Table 2, which were strongly positive for Ptxl protein by immunohistochemistry. The Ptxl antibodies revealed a band of $34 \mathrm{kDa}$ in an immunoblot of both $\mathrm{GH}$-secreting adenoma and PRL-secreting adenoma (Fig. 6).

\section{RT-PCR Analysis}

In five human non-neoplastic pituitaries and 73 pituitary adenomas, a representative human non-neoplastic pituitary and 18 pituitary adenomas, including the six GH-secreting adenomas, two PRL-secreting adenomas, two ACTH-secreting adenomas, two TSH-secreting adenomas, two null cell adenomas, and four gonadotropin-subunit-positive adenomas, were available for RT-PCR in this study. Table 4 indicates the clinical and endocrinologic feature in 18 pituitary adenomas examined for RT-PCR, and two GH-secreting adenomas were immunohistochemically negative for Ptxl protein in this series. The results of RT-PCR are shown to Figure 7. Analysis of human Ptxl messenger RNA (mRNA) indicated that the expected 470 bp PCR product was detected by ethidium bromide staining in one human non-neoplastic pituitary and in all of 18 pituitary adenomas. Interestingly, two GH-secreting adenomas indicating lane G4 and G6, which were negative for Ptxl protein by immunohistochemistry, were expressed Ptxl mRNA. The control RT-PCR experiment, using total RNA extracted from human non-neoplastic pituitary without reverse transcriptase, was negative for human Ptxl mRNA. 


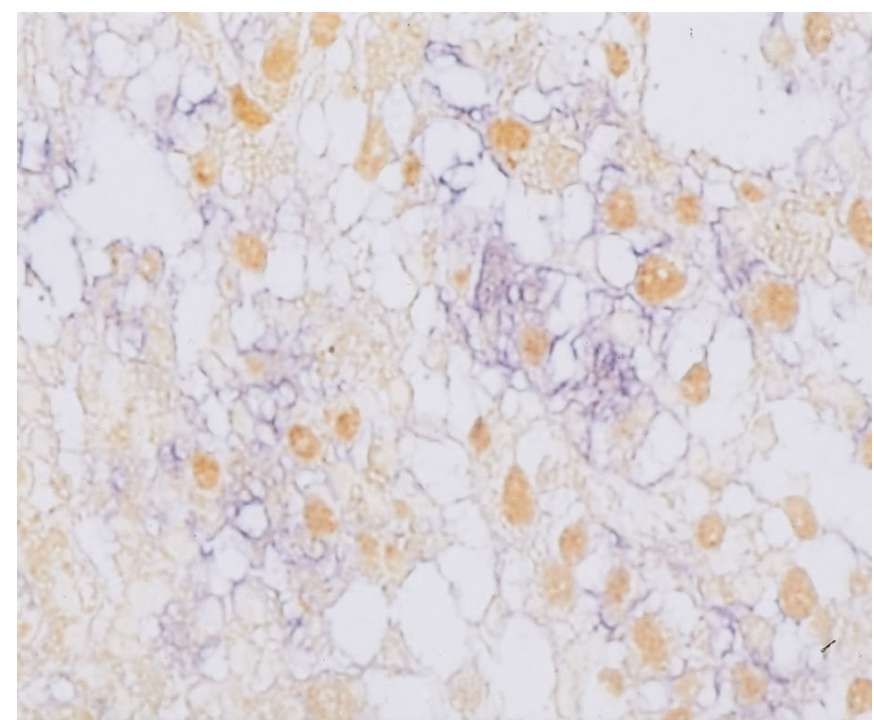

FIGURE 2. Immunohistochemical detection of Ptxl protein in ACTH-secreting adenomas. Immunoreactivity for Ptxl protein is observed in the nuclei of adenoma cells and often co-localized with ACTH positive cells (original magnification, $600 \times$ ).

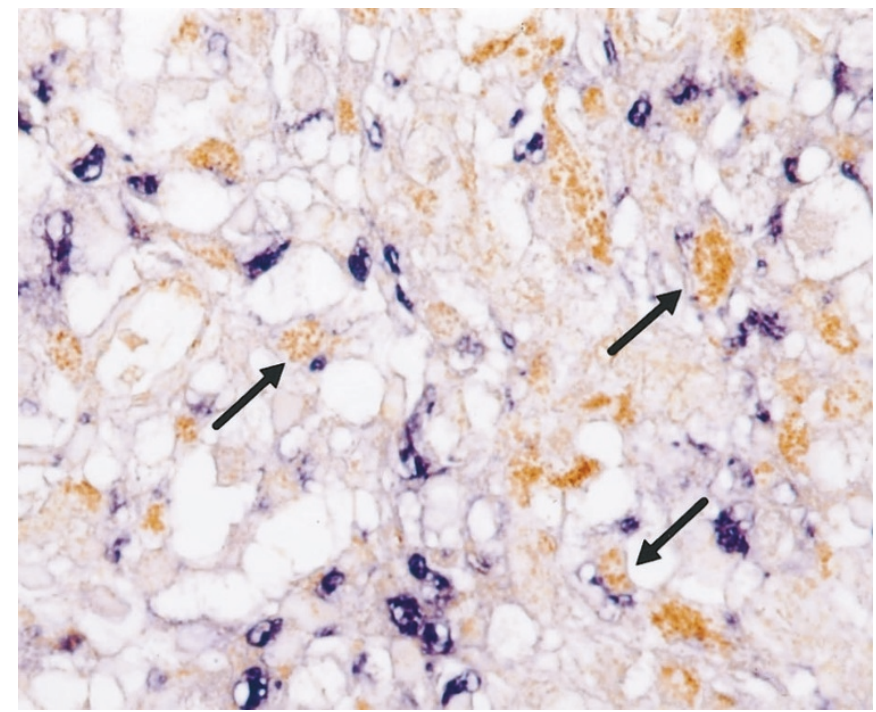

FIGURE 3. Immunohistochemical detection of Ptxl protein in PRL-secreting adenomas. Immunoreactivity for Ptxl protein is observed in the nuclei of adenoma cells and occasionally co-localized with PRL positive cells (arrows) (original magnification, 600×).

\section{DISCUSSION}

The pituitary gland develops from Rathke's pouch and its primordium appears on e8.5 in mice. It has been suggested that the hormone-producing cells of the pituitary gland initially appear as $\alpha$-SU positive cells on e11 and subsequently differentiate into anterior pituitary hormone secreting cells (27). Particularly, the mechanism by which anterior pituitary hormone secreting cells undergo functionally specific differentiation has been the major issue in pituitary research. As a key to answer this question, considerable attention has been paid to transcription factors that are specific to the pituitary gland. In 1988, Bodner et al. (28) and Ingraham et al. (29) separately reported the presence of a pituitary specific transcription factor (Pit-1/GHF-1).
Pit-1 was found in the nuclear extract of rat pituitary cells and was shown to enhance the transcription of GH and PRL (30). In addition, Pit-1 was found to activate transcription of the gene for $\mathrm{TSH} \beta$ (31-33) and to play a role in the functional differentiation of these cells as well as in the maintenance of their viability and proliferation (34-36). There have been several studies on the expression of Pit-1 in human pituitary adenomas (1-6).

It has been recently shown that another transcription factor is also involved in the functional differentiation of pituitary cells. Pituitary homeo box 1 (Ptx1) is a transcription factor first reported by Lamonerie et al. (17) that has been suggested to play a role in the transcription of POMC because it specifically binds to the nucleus of AtT20 cells, a 

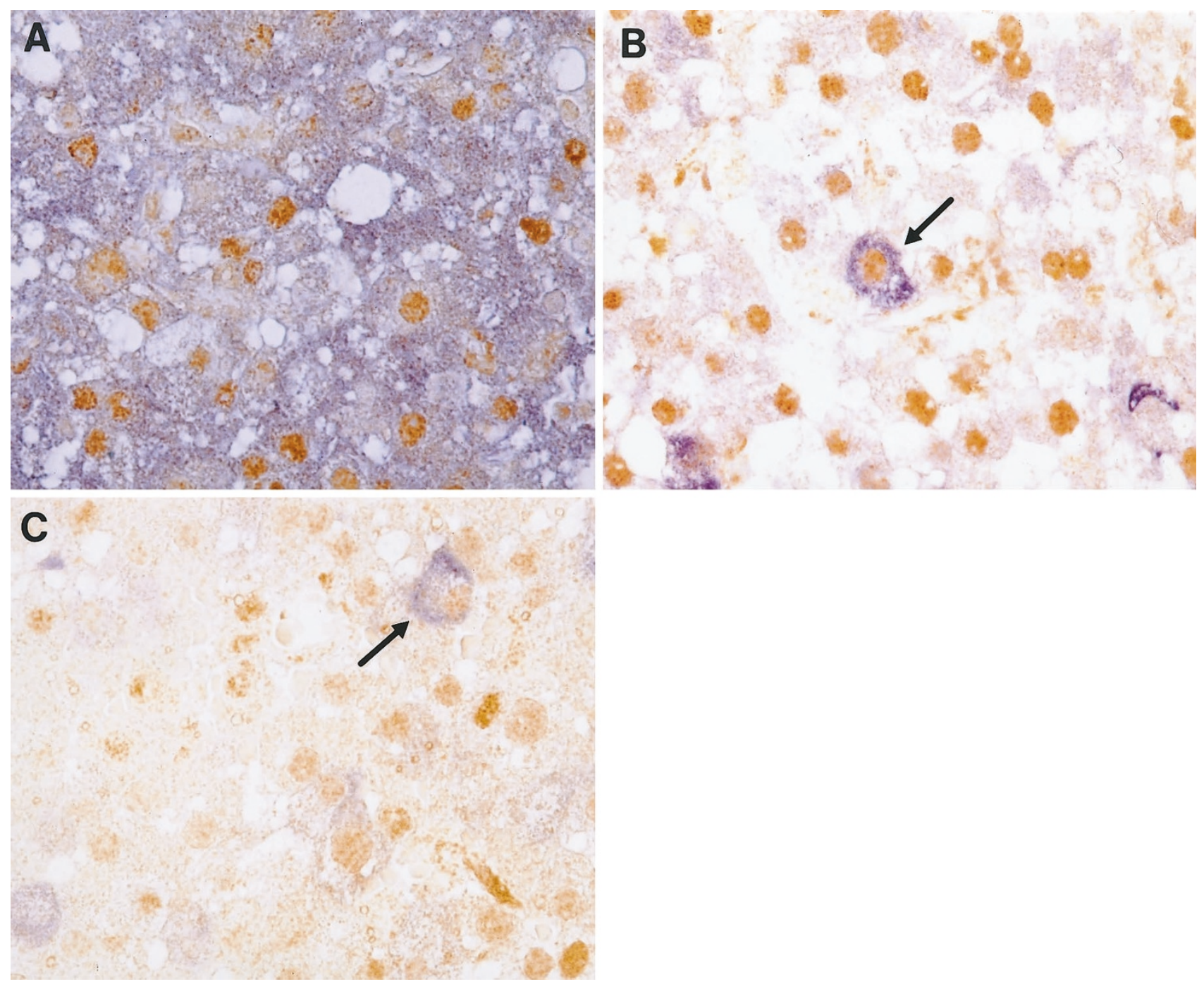

FIGURE 4. Immunohistochemical detection of Ptxl protein in GH-secreting adenomas. Immunoreactivity for Ptxl protein is observed in the nuclei of adenoma cells and often co-localized with GH positive cells (A), and occasionally co-localized with PRL (arrow) (B), and $\alpha$-SU (arrow) (C) (original magnification, $600 \times$ ).

murine corticotroph cell line. Ptx1 is closely related to the mammalian Otx gene, which is expressed in the rostral brain during the process of development $(37,38)$, and Otx2 is a fundamental factor related to forebrain and midbrain development in mice (39). Ptxl mRNA is strongly expressed in adult corticotroph cells, which secrete POMC, whereas its expression in Rathke's pouch has also been detected using the in situ hybridization technique (17). Thus, there remains a possibility that Ptxl is expressed in pituitary cells other than corticotrophs, so that its activities need further investigation, including the relationship with other transcription factors related to pituitary cells.

Recent investigations using cultured cells have shown that Ptxl is not only involved with POMC transcription in corticotrophs but also with the transcription of other anterior pituitary hormones. Tremblay et al. (16) investigated Ptxl expression in AtT20 cells, a corticotroph cell line used for Ptxl cloning, as well as in $\alpha \mathrm{T} 3-1$ cells (gonadotroph precursor), $\alpha \mathrm{TSH}$ cells (thyrotroph precursor), GHFT1.5 cells (somatolactotroph precursor), $\mathrm{GH}_{3}$ cells (a somatolactotroph cell line), $\mathrm{GH}_{4} \mathrm{C}_{1}$ cells, and TtT-97 cells (thyrotroph tumor). They showed by Northern blotting that the Ptx1 mRNA level was higher in $\alpha \mathrm{T} 3-1, \alpha \mathrm{TSH}$, and GHFT1.5 cells than in AtT20 cells, indicating the possibility that Ptx1 is actively involved in pituitary cells other than corticotrophs (16). More recently, it has been found that Ptxl is expressed in all pituitary cells, but is differentially expressed in different lineages at both the mRNA and protein levels. Especially, the highest levels of Ptxl expression were observed in $\alpha$-SU positive cells (40). However, previous studies were performed in mammalians (such as rats) or on cultured cells, and no studies have been performed extensively on the human tissues. Only Ptxl mRNA expression was demonstrated by Pellegrini-Bouiller et al. (41) using RT-PCR methods in human pitu- 


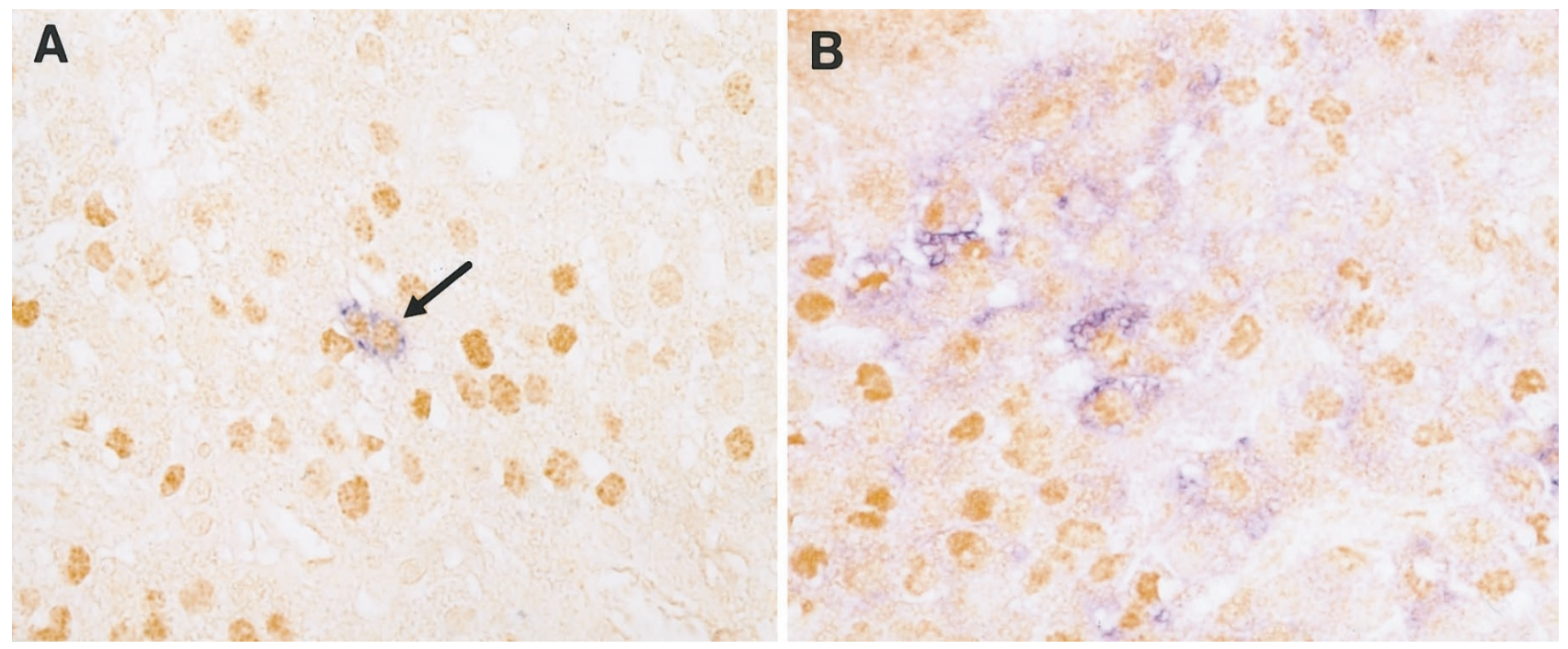

FIGURE 5. Immunohistochemical detection of Ptxl protein in gonadotropin-subunit-positive adenomas. In this case, Ptxl immunopositivity was occasionally co-localized with $\alpha$-SU (arrow) (A), and FSH $\beta$ positive cells (B) (original magnification, 600×).

\section{M.W. \\ (kDa)}

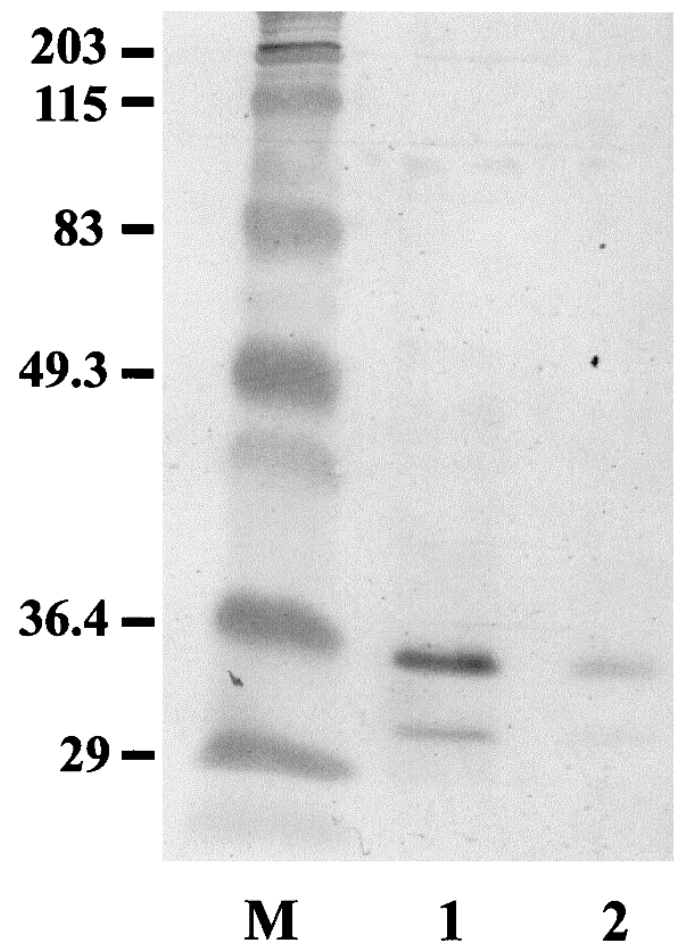

FIGURE 6. Western blotting for Ptxl protein in human pituitary adenomas. The Ptxl antibodies detected a band of $34 \mathrm{kDa}$ in immunoblot of both GH-secreting adenoma and PRL-secreting adenoma. These adenomas were indicated by the case of No. 1 and 19 respectively in the Table 2. (Lane 1, GH-secreting adenoma; Lane 2, PRL-secreting adenoma).

itary adenomas. In the present study, we first report Ptxl protein expression by immunohistochemistry in normal human pituitary tissues and pituitary adenomas as well as its mRNA expression by RTPCR. We detected Ptxl protein in the nuclei of all
TABLE 4. Summary of Representative 18 Pituitary Adenomas for RT-PCR Analysis

\begin{tabular}{|c|c|c|c|c|}
\hline Diagnosis & $\begin{array}{l}\text { Case } \\
\text { No. }\end{array}$ & $\begin{array}{l}\text { Age/ } \\
\text { Sex }\end{array}$ & $\begin{array}{l}\text { Tumor } \\
\text { Size }\end{array}$ & $\begin{array}{l}\text { Case No. } \\
\text { (In Table 2) }\end{array}$ \\
\hline \multirow[t]{6}{*}{ Acromegaly } & G1 & $62 / F$ & M & 1 \\
\hline & G2 & $46 / F$ & $\mathrm{M}$ & 2 \\
\hline & G3 & $62 / \mathrm{M}$ & M & 3 \\
\hline & G4 & $50 / \mathrm{F}$ & M & 5 \\
\hline & G5 & $41 / \mathrm{M}$ & M & 6 \\
\hline & G6 & $71 / \mathrm{F}$ & IM & 11 \\
\hline \multirow{2}{*}{$\begin{array}{l}\text { PRL secreting } \\
\text { adenoma }\end{array}$} & $\mathrm{P} 1$ & $21 / F$ & $\mathrm{M}$ & 19 \\
\hline & P2 & $63 / F$ & M & 26 \\
\hline \multirow[t]{2}{*}{ Cushing's } & $\mathrm{A} 1$ & $44 / F$ & IM & 30 \\
\hline & A2 & $18 / F$ & M & 46 \\
\hline \multirow{2}{*}{$\begin{array}{l}\text { TSH secreting } \\
\text { adenoma }\end{array}$} & $\mathrm{T} 1$ & $59 / F$ & IM & 52 \\
\hline & $\mathrm{T} 2$ & $49 / F$ & M & 53 \\
\hline \multirow[t]{2}{*}{ Null cell adenoma } & Nul & $71 / \mathrm{F}$ & M & 58 \\
\hline & $\mathrm{Nu} 2$ & $62 / \mathrm{M}$ & M & 62 \\
\hline \multirow{4}{*}{$\begin{array}{c}\text { Gonadotropin-subunit } \\
\text { positive adenoma }\end{array}$} & Gn1 & $80 / \mathrm{M}$ & M & 64 \\
\hline & $\mathrm{Gn} 2$ & $48 / \mathrm{F}$ & M & 67 \\
\hline & Gn3 & $63 / F$ & M & 68 \\
\hline & Gn4 & $79 / \mathrm{M}$ & M & 69 \\
\hline
\end{tabular}

M, macroadenoma; IM, intrasellar macroadenoma.

types of anterior pituitary hormone secreting cells, indicating that Ptxl is a nuclear binding protein. This protein was also observed extensively in all types of pituitary adenoma, although some $\mathrm{GH}$ secreting adenomas, ACTH-secreting adenomas, TSH-secreting adenomas, and nonfunctioning adenomas were negative for Ptxl protein. This may indicate that another transcription factor, such as Pit-1, is also involved synergistically in functional expression of the adenoma cells, although technical problems on antigen preservation in the specimens may also have to be considered. In our investigation of Ptxl mRNA by RT-PCR, this mRNA was detected in all patients analyzed, including two GH- 


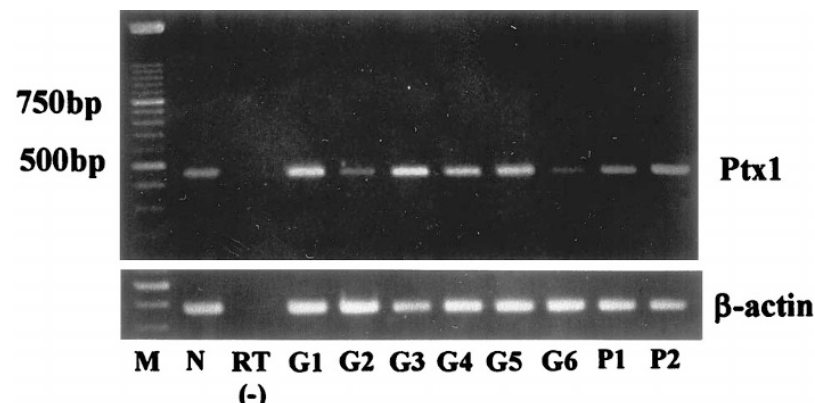

(-)

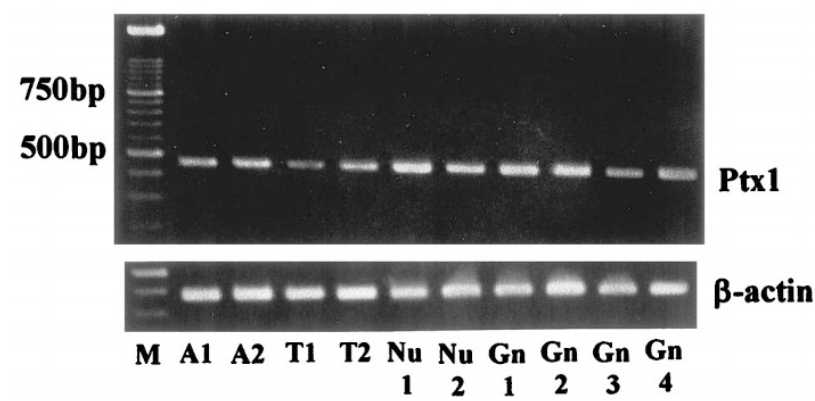

FIGURE 7. RT-PCR of human non-neoplastic pituitary and pituitary adenomas for Ptxl mRNA. One non-neoplastic pituiary and all eighteen pituitary adenomas, containing six GH-secreting adenomas (G1-G6), two PRL-secreting adenomas (P1, P2), two ACTH-secreting adenomas (A1, A2), two TSH-secreting adenomas (T1, T2), two null cell adenomas (Nu1, Nu2), and four gonadotropin-subunit-positive adenomas (Gn1Gn4), have expression of Ptxl mRNA. Two of six GH-secreting adenomas $(\mathrm{G} 4, \mathrm{G} 6)$ which were immunohistochemically negative for Ptxl protein, also have expression of Ptxl mRNA, but one of its two cases (G6) were faint signal for Ptxl mRNA. RT(-) indicates a negative control without reverse transcription in human non-neoplastic pituitary.

secreting adenomas negative for Ptxl protein. Based on the above results, it seems that Ptxl has no hormone-related specificity and is involved in the transcription of all types of anterior pituitary cells. This finding appears to be consistent with the previous report by Pellegrini-Bouiller et al. (41).

Regarding the role of Ptxl in the functional differentiation of pituitary cells, an in vitro study has suggested that at least one Ptxl binding site exists in the promoter region for anterior pituitary hormones such as POMC and that Ptxl enhances the activity of such promoters (16). The synergistic actions between Ptxl and transcription factors for other types of pituitary cells have also been reported, particularly Ptxl synergy with NeuroD1/ $\beta 2$, which is the transcription factor containing a helix-loop-helix heterodimer to activate POMC transcription (42-45). On the other hand, Ptxl is thought to be in synergy with SF-1/ Ad4BP, which is a transcription factor regulating the P-450 gene, to enhance the promoter activity of $\operatorname{LH} \beta(16,46-49)$. Lastly, synergistic action of Pit-1 with Ptxl has also been reported in the case of PRL promoter activity $(16,50)$. In the present study, Ptxl expression was observed in $100 \%$ of PRL-secreting adenomas, suggesting that Ptxl may be of synergy with Pit-1 in the functional differentiation of these adenomas.

The evidence that has been accumulated regarding the involvement of Ptxl in the transcription of $\alpha$-SU and P-Lim/Lhx-3 seems to be involved in $\alpha$-SU transcription as a cofactor of Ptxl (51). P-Lim/ Lhx-3 mRNA initially appears in Rathke's pouch on e8.5 to 9, and it is known that four types of anterior pituitary cells including $\alpha$-SU are completely depleted in P-Lim/Lhx-3 deficient knockout mice (52). An experiment using a Ptxl knockout cell line showed that expression of the $L h x$-3 gene was decreased remarkably compared with that of the $\alpha-S U$ gene (16), and this indicates that Ptxl is essential for $\operatorname{Lh} x$-3 gene expression. Although P-Lim/Lhx-3 was not analyzed in the present study, it appears necessary to investigate the expression of P-Lim/ Lhx-3 and its association with Ptxl in pituitary adenomas, especially in the $\alpha$-SU positive adenomas.

As a summary, Ptx1 is expressed in all types of pituitary adenomas and is speculated to play a role in the transcription factor in synergy with the other factors to define the specific hormone production. Therefore, Ptxl is one of the recently reported and inevitable transcription factors in pituitary tumors. Along with the advances of molecular biology in recent years, many factors involved in pituitary cell function have been identified. These factors appear to interact with each other in a complex manner and it would be of great interest if such interactions could be clarified further.

Acknowledgments: The authors thank Drs. Noboru Yanaihara, Kiyoteru Komatsubara, Makoto Sugiyama, and Yoshiko Itoh for their technical assistance, and Dr. Johbu Itoh for his photographic assistance.

\section{REFERENCES}

1. Friend KE, Chiou YK, Laws ER. Pit-1 messenger ribonucleic acid is differentially expressed in human pituitary adenomas. J Clin Endocrinol Metab 1993;77:1281-6.

2. Lloyd RV, Jin L, Chandler WF. Pituitary specific transcription factor messenger ribonucleic expression in adenomatous and nontumorous human pituitary tissues. Lab Invest 1993; 69:570-5.

3. Asa SL, Pu LA, Lew AM. Cell type-specific expression of the pituitary transcription activator Pit-1 in the human pituitary and pituitary adenomas. J Clin Endocrinol Metab 1993;77: 1275-80.

4. Pellegrini I, Barlier A, Gunz G. Pit-1 gene expression in the human pituitary and pituitary adenomas. J Clin Endocrinol Metab 1994;79:189-96.

5. Sanno N, Teramoto A, Matsuno A, Osamura RY. Expression of human Pit-1 product in the human pituitary and pituitary adenomas. Arch Pathol Lab Med 1996;120:73-7. 
6. Sanno N, Teramoto A, Matsuno A, Itoh J, Takekoshi S, Osamura RY. In situ hybridization analysis of Pit-1 mRNA and hormonal production in human pituitary adenomas. Acta Neuropathol 1996;91:263-8.

7. Day RN, Koike S, Sakai M, Muramatsu M, Maurer RA. Both Pit-1 and the estrogen receptor are required for estrogen responsiveness of the rat prolactin gene. Mol Endocrinol 1990;4:1964-71.

8. Schaufele F, West BL, Baxter JD. Synergistic activation of the rat growth hormone promoter by Pit-1 and the thyroid hormone receptor. Mol Endocrinol 1992;6:656-65.

9. Sanchez-Pacheco A, Palomino T, Aranda A. Retinoic acid induces expression of the transcription factor GHF-1/Pit-1 in pituitary prolactin- and growth hormone-producing cell lines. Endocrinology 1995;136:5391-8.

10. Sanno N, Teramoto A, Matsuno A, Takekoshi S, Itoh J, Osamura RY. Expression of Pit-1 and estrogen receptor messenger RNA in prolactin-producing pituitary adenomas. Mod Pathol 1996;9:526-33.

11. Theill LE, Karin M. Transcriptional control of GH expression and anterior pituitary development. Endocr Rev 1993;14: 670-89.

12. Sornson MW, Wu W, Dasen JS, Flynn SE, Norman DJ, O'Connell SM, et al. Pituitary lineage determination by the prophet of Pit-1 homeodomain factor defective in Ames dwarfism. Nature 1996;384:327-33.

13. Thomas PQ, Johnson BV, Rathjen J, Rathjen PD. Sequence, genomic organization, and expression of the novel homeobox gene hesx1. J Biol Chem 1995;270:3869-75.

14. Hermesz E, Mackem S, Mahon KA. Rpx: a novel anteriorrestricted homeobox gene progressively activated in the prechordal plate, anterior neural plate and Rathke's pouch of the mouse embryo. Development 1996;122:41-52.

15. Gage PJ, Brinkmeier ML, Scarlett LM, Knapp LT, Camper SA, Mahon KA. The Ames dwarf gene, $d f$, is required early in pituitary ontogeny for the extinction of Rpx transcription and initiation of lineage-specific cell proliferation. Mol Endocrinol 1996;10:1570-81.

16. Tremblay JJ, Lanctot C, Drouin J. The pan-pituitary activator of transcription, Ptx1 (pituitary homeobox 1), acts in synergy with SF-1 and Pit-1 and is an upstream regulator of the Lim-homeodomain gene Lim3/Lhx3. Mol Endocrinol 1998; 12:428-41.

17. Lamonerie T, Tremblay JJ, Lanctot $C$, Therrien M, Gauthier Y, Drouin J. Ptxl, a bicoid-related homeo box transcription factor involved in transcription of the pro-opiomelanocortin gene. Genes Dev 1996;10:1284-95.

18. Sanno N, Teramoto A, Matsuno A, Inada K, Itoh J, Osamura RY. Clinical and immunohistochemical studies on TSHsecreting pituitary adenoma: its multihormonality and expression of Pit-1. Mod Pathol 1994;7:893-9.

19. Sanno N, Teramoto A, Matsuno A, Takekoshi S, Osamura RY. GH and PRL gene expression by nonradioisotopic in situ hybridization in TSH-secreting pituitary adenomas. J Clin Endocrinol Metab 1995;80:2518-22.

20. Sanno N, Teramoto A, Osamura RY. Clinical and cytofunctional classification of pituitary adenomas: Proposal of a new classification. Acta Neurochir 1996;138:1186-92.

21. Sanno N, Osamura RY. Molecular pathology of the pituitary adenomas. Endocrine Pathol 1997;8:137-42.

22. Kurotani R, Tahara S, Sanno N, Teramoto A, Pamela L Mellon, et al. Expression of Ptxl in the adult rat pituitary glands and pituitary cell lines hormone secreting cells and folliculostellate (FS) cells. Cell Tissue Res 1999;298:55-61.

23. Crawford MJ, Lanctot C, Tremblay JJ, Jenkins N, Gilbert D, Copeland N, et al. Human and murine PTX1/Ptx1 gene maps to the region for Treacher Collins syndrome. Mamm Genome 1997;8:841-5.
24. Hsu SM, Raine L, Fanger H. Use of avidin biotin-peroxidase complex $(\mathrm{ABC})$ in immunoperoxidase techniques: a comparison between $\mathrm{ABC}$ and unlabeled antibody (PAP) procedures. J Histochem Cytochem 1981;29:577-80.

25. Nakane PK. Simultaneous localization of multiple tissue antigens using the peroxidase-labeled antibody method: a study on pituitary glands of the rat. J Histochem Cytochem 1968;16:557-60.

26. Fields K, Kulig E, Lloyd RV. Detection of prolactin messenger RNA in mammary and other normal and neoplastic tissues by polymerase chain reaction. Lab Invest 1993;68:354-60.

27. Voss JW, Rosenfeld MG. Anterior pituitary development: short tales from dwarf mice. Cell 1992;70:527-30.

28. Bodner M, Castrillo JL, Theill LE, Deerinck T, Ellisman M, Karin M. The pituitary-specific transcription factor GHF-1 is a homeobox-containing protein. Cell 1988;55:505-18.

29. Ingraham HA, Chen RP, Mangalam HJ, Elsholtz HP, Flynn $\mathrm{SE}$, Lin CR, et al. A tissue specific transcription factor containing a homeodomain specifies a pituitary phenotype. Cell 1988;55:519-29.

30. Mangalam HJ, Albert VR, Ingraham HA, Kapiloff M, Wilson L, Nelson C, Elsholtz H, Rosenfeld MG. A pituitary POU domain protein, Pit-1 activates both growth hormones and prolactin promoters transcriptionally. Gene Dev 1989;3:94658.

31. Li S, Crenshaw EB, Rawson EJ, Simmons DM, Swanson LW, Rosenfeld MG. Dwarf locus mutants lacking three pituitary cell types result from mutations in the POU-domain gene Pit-1. Nature 1990;347:528-33.

32. Steinfelder HJ, Hauser P, Nakayama Y, Radovick S, McClaskey JH, Taylor T, et al. Thyrotropin-releasing hormone regulation of human TSHB expression: role of a pituitaryspecific transcription factor (Pit-1/GHF-1) and potential interaction with a thyroid hormone-inhibitory element. Proc Natl Acad Sci U S A 1991;88:3130-4.

33. Steinfelder HJ, Radovick S, Mroczynski MA, Hauser P, McClaskey JH, Weintraub BD, et al. Role of a pituitary specific transcription factor (Pit-1/GHF-1) or a closely related protein in cAMP regulation of human thyrotropin- $\beta$ subunit gene expression. J Clin Invest 1992;89:409-19.

34. Dolle P, Castrillo JL, Theill LE, Deerinck T, Ellisman M, Karin M. Expression of GHF-1 protein in mouse pituitaries correlates both temporally and spatially with the onset of growth hormone gene activity. Cell 1990;60:809-20.

35. Simmons DM, Voss JW, Ingraham HA, Holloway JM, Broide RS, Rosenfeld MG, et al. Pituitary cell phenotypes involve cell-specific Pit-1 mRNA translation and synergistic interactions with other transcription factors. Gene Dev 1990;4:695711.

36. Castrillo JL, Theill LE, Karin M. Function of the homeodomain protein GHF 1 in pituitary cell proliferation. Science 1991;253:197-9.

37. Simeone A, Acampora D, Mallamaci A, Stornaiuolo A, Boncinelli E. Nested expression domains of four homeobox genes in developing rostral brain. Nature 1992;358:687-90.

38. Simeone A, Acampora D, Mallamaci A, Stornaiuolo A, D'Apice MR, Nigro V, et al. A vertebrate gene related to orthodenticle contains a homeodomain of the bicoid class and demarcates anterior neuroectoderm in the gastrulating mouse embryo. EMBO J 1993;12:2735-47.

39. Acampora D, Mazan S, Lallemand Y, Avantaggiato V, Maury $\mathrm{M}$, Simeone A, et al. Forebrain and midbrain regions are deleted in Otx-2 $2^{-/-}$mutants due to a defective anterior neuroectoderm specification during gastrulation. Development 1995;121:3279-90.

40. Lanctot C, Gauthier Y, Drouin J. Pituitary homeobox 1 (Ptx1) is differentially expressed during pituitary development. Endocrinology 1999;140:1416-22. 
41. Pellegrini-Bouiller I, Manrique C, Gunz G, Grino M, Zamora AJ, Figarella-Branger D, et al. Expression of the members of the Ptxl family of transcription factors in human pituitary adenomas. J Clin Endocrinol Metab 1999;84:2212-20.

42. Therrien M, Drouin J. Cell-specific helix-loop-helix factor required for pituitary expression of the proopiomelanocortin gene. Mol Cell Biol 1993;13:2342-53.

43. Poulin G, Turgeon B, Drouin J. NeuroD1/ $\beta 2$ contributes to cell-specific transcription of the $P O M C$ gene. Mol Cell Biol 1997;17:6673-82.

44. Lee JE, Hollenberg SM, Snider L, Turner DL, Lipnick N, Weintraub H. Conversion of Xenopus ectoderm into neurons by NeuroD, a basic helix-loop-helix protein. Science 1995;268:836-44.

45. Naya FJ, Stellrecht CMM, Tsai MJ. Tissue-specific regulation of the insulin gene by a novel basic helix-loop-helix transcription factor. Gene Dev 1995;9:1009-19.

46. Lala DS, Rice DA, Parker KL. Steroidogenic factor 1, a key regulator of steroidogenic enzyme expression, is the mouse homolog of fushi tarazu-factor 1. Mol Endocrinol 1992;6: 1249-58.

47. Morohashi K, Honda S, Inomata Y, Handa H, Omura T. A common trans-acting factor, Ad4-binding protein, to the promoters of steroidogenic P-450s. J Biol Chem 1992;267: 17913-9.

48. Honda S, Morohashi K, Nomura M, Takeya M, Kitajima M, Omura T. Ad4BP regulating steroidogenic P-450 gene is a member of steroid hormone receptor superfamily. J Biol Chem 1993;268:7494-502.

49. Morohashi K, Zanger UM, Honda S, Hara M, Waterman MR, Omura T. Activation of CYP11A and CYP11B gene promoters by the steroidogenic cell-specific transcription factor, Ad4BP. Mol Endocrinol 1993;7:1196-204.

50. Szeto DP, Ryan AK, O'Connell SM, Rosenfeld MG. P-OTX: a PIT-1-interacting homeodomain factor expressed during anterior pituitary gland development. Proc Natl Acad Sci U S A 1996;93:7706-10.

51. Bach I, Carriere C, Ostendorff HP, Andersen B, Rosenfeld MG. A family of LIM domain-associated cofactors confer transcriptional synergism between LIM and Otx homeodomain proteins. Gene Dev 1997;11:1370-80.

52. Sheng HZ, Zhadanov AB, Mosinger B Jr, Fujii T, Bertuzzi S, Grinberg A, et al. The LIM homeobox gene Lhx-3 is essential for the specification and proliferation of pituitary cell lineages. Science 1996;256:1555-60. 